\section{The Invisibilities of Political Torture}

Berenike Jung. (2020). The

Invisibilities of Political Torture. Visual

Evidence in US and Chilean Cinema

and Television. Edinburgh: Edinburgh

University Press. 249 páginas. ISBN

9781474437011

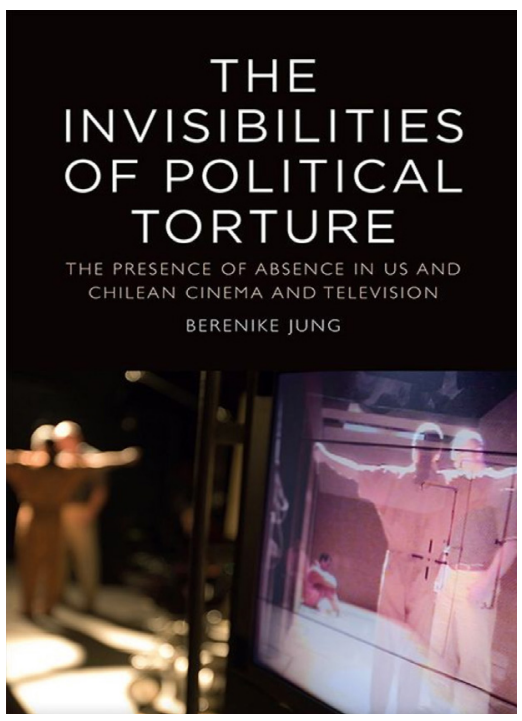

Este libro revisa, discute y reflexiona en profundidad la representación de un tipo de violencia política, la tortu$\mathrm{ra}$, en producciones audiovisuales de ficción en Estados Unidos y en Chile. El trabajo no es propiamente comparativo, aunque en la elección de las piezas audiovisuales de ambos países lo que se intenta es realizar una operación de similitud y contraste. El objeto central, o más bien el punto de partida de su reflexión, es la tortura definida en los términos de la "Convención contra la Tortura y otros tratos crueles, inhumanos o degradantes", de 1984, como "todo acto por el cual se inflija intencionadamente a una persona dolores o sufrimientos graves, ya sean físicos o mentales, con el fin de obtener de ella o de un tercero, información o una confesión..." (Jung, 2020, p.6).

¿Y por qué la tortura? Por varias razones. Primero porque en el caso de la revisión fílmica de la producción estadounidense, la tortura es explícita y está muy bien documentada. En ese sentido, "es visible". Esto no es lo que ocurre con el caso chileno abordado, pues, aunque el uso de la tortura ha sido documentado, no existen muchas evidencias visibles de la misma, por lo cual ésta es, más bien, recreada en la ficción. Segundo, porque a pesar de que la tortura está prohibida y sancionada en muchos países - pues supone una violación a los derechos humanos-, su uso en la actualidad no es aislado, sino más bien aparece como un instrumento bastante utilizado en las distintas "guerras" (internas y externas) que se desarrollan y que, además, justificarían la existencia de tropas y grupos de élite. La construcción de un "enemigo" justificaría, además, la necesidad de la compra de armamento y la utilización de armas y tecnología de vanguardia como equipamiento necesario para enfrentar esta amenaza. Esto último es, también, parte del análisis que realiza la autora del libro en uno de sus capítulos.

La tortura aparece, entonces, como un instrumento que, aunque cuestionable, permite la protección de un bien común: la paz, necesaria para el desarrollo de la vida cotidiana, pero también permitiría resguardar el desarrollo de las operaciones de mercado. Es lo que la autora plantea en relación a la utilización de la tortura durante la dictadura en Chile, la que habría ayudado a instalar la ideología base del capitalismo, con ayuda precisamente de Estados Unidos. Aquí veríamos, entonces, una conexión entre los dos universos fílmicos considerados y quizás, aunque no está dicho, la justificación de la elección del corpus.

En el caso estadounidense, la autora trabaja con películas ly documentales) relacionadas con la visibilización de la tortura de prisioneros a partir de la exposición de las fotografías capturadas en 2004 en la prisión de Abu Ghraib en Irak y, sobre estos registros, se pregunta por la (in)justificación del uso de estos métodos en la lucha contra el terrorismo (justificadas, en parte, por los ataques a las Torres Gemelas). Mientras que, en el caso chileno, son las producciones que abordan la dictadura (1973) y sus consecuencias en los individuos, pero también en la sociedad.

Mientras que, en el primer caso, como lo habíamos indicado previamente, nos enfrentamos a la visibilidad de la práctica de la tortura, en el segundo nos encontramos con las secuelas de ésta, es decir, con su invisibilidad, con la "presencia de la ausencia o el proceso de hacerla invisible" (Jung, 2020, p. 16, destacado en el original).

El libro está organizado en ocho capítulos, más una introducción y una conclusión. La introducción discute conceptualmente la tortura en el contexto actual y cómo se representa visualmente. Este es el puntapié inicial que permite presentar y analizar su manifestación visible en películas como Zero Dark Thirty (2012, Kathryn Bigelow) y series como 24 (20012010, 8 temporadas) y Homeland (2011-2020, 8 temporadas).

Los tres primeros capítulos desarrollan el análisis que no sólo trabaja con los textos audiovisuales sino también con las instancias de producción y las 
condiciones de recepción, incorporando aquí a las emociones. Destaco en el análisis el recorrido de lectura que el punto de vista desde el cual se construye el relato sugiere: a veces miramos las películas empatizando con los torturadores, otras con las víctimas y también las experimentamos como testigos.

En el capítulo 5, al analizar los documentales de Errol Morris The Unknown Known (2014) y Standard Operating Procedure (2008), la autora nos invita a reflexionar sobre el estatus de las imágenes al "investigar las formas en que los medios crean y dan forma a nuestra percepción del evento de tortura y el papel que juega el lenguaje en este proceso" (Jung, 2020, p.17).

En el caso chileno, en el capítulo 4, se abordan como ejemplos que incorporan imágenes de tortura las series Los archivos del Cardenal (2011-2014, 2 temporadas) y Los 80 (2008-2014, 7 temporadas) discutiendo en estos casos la relación entre estas producciones y la memoria. Si bien la tortura aparece de manera explícita en ambos textos audiovisuales (sobre todo en Los archivos del Cardenall se destaca la forma en que estéticamente se construye lo que es considerado indecible. Utiliza para ilustrar esto las películas Pena de muerte (2012, Tevo Díaz) y Carne de perro (2012, Fernando Guzzoni).

El capítulo 7, a partir del análisis de las películas de Pablo Larraín Post Morten (2010) y Tony Manero (2008) además de La Danza de la realidad (2013, Alejandro Jodorowsky), revisa lo que considera alienaciones específicas de la sociedad neoliberal construidas en la postdictadura. Mientras que, en el último capítulo, con Nostalgia de la luz (2010, Patricio
Guzmán) y No (2012, Pablo Larraín) explora el vínculo con el referente externo (con los hechos o la historia) de estos registros y su importancia para la construcción de memorias del periodo.

Vemos, así, que el corpus de películas y series elegidas son aquellas producidas entre 2008 y 2020 y referidas a dos hitos mediáticos en el caso estadounidense lel atentado a las Torres Gemelas y el escándalo de las fotos de torturas en la prisión de Abu Ghraib), y conmemorativos en el caso chileno (los 40 años del golpe de Estado). En ambos casos, analizar la tortura significa para la autora abordar un secreto a voces, a medias conocido y a medias invisible. Así, la ficción audiovisual en películas y series saca a la luz la parte invisible de la historia, de estas historias. Aquellas que se quiere olvidar, borrar u obscurecer, pero también empuja al extremo las categorías que se pueden utilizar para hacer visibles estos hechos y su impacto colectivo experiencial y emocional.

En las conclusiones aparece el contraste entre las formas de hacer visible la tortura (con el análisis visual de su representación en la pantalla) y las formas de, sin necesariamente mostrarlas, hacerlas evidentes, sobre todo en relación a sus consecuencias, en el caso chileno. En éstas, la pena se carga en el cuerpo y se expresa en la vida.

Las estrategias estéticas usadas, visibilizando o no la tortura, nos muestran, desde una cercanía afectiva, los efectos de esta violencia para una sociedad y, al hacerlo, construyen una lectura ética sobre este tema. La ficción audiovisual opera, entonces, como una prótesis (Landsberg, 2004) que recrea el pasado, los pasados difíciles y permiten su actualización e incorporación como experiencias significativas mediadas por los afectos. Así, estas ficciones se constituyen en artefactos de memoria (Frei, 2015) que, al ser interpretaciones desde el presente, se ajustan a los climas sociales o de época (Jelin, 2001), enriqueciendo los marcos sociales de interpretación existentes y los aprendizajes para la vida. Este libro colabora con esta tarea.

\section{Lorena Antezana Barrios}

Profesora Asociada

Universidad de Chile

lantezanaduchile.cl

\section{Referencias}

Frei, R. (2015). The living bond of generations. The narrative construction of post-dictatorial memories in Argentina and Chile. Tesis Doctorado en Filosofía. Universidad de Berlín.

Jelin, E. (2001). Los trabajos de la memoria. España: Siglo Veintiuno editores.

Landsberg, A. (2004). Prosthetic memory: The transformation of American Remembrance in the Age of Mass Culture. Nueva York: Columbia University Press. 